\title{
MODEL MATEMATIKA PENYAKTI DIABETES MELITUS
}

\author{
Muh. Irwan ${ }^{1}$, Irwan $^{2}$, jusrawati ${ }^{3}$ \\ ${ }^{1,2,3}$ Dosen Universitas Islam Negeri Alauddin Makassar \\ e-mail :muhirwan@uin-alauddin.ac.id ${ }^{1}$,irwan.msi@uin-alauddin.ac.id ${ }^{2}$ \\ jusrawati@gmail.com ${ }^{3}$
}

\begin{abstract}
Diabetes mellitus (DM) or often known as diabetes mellitus, is a disease that can be caused by heredity, one of the factors caused by patterns of human life patterns. In the paper a model and mathematical analysis of DM disease are introduced. To simplify the analysis, the Runge Kutta method was used to complete the model. Based on the results of the analysis, it is known that the population of patients with DM disease tends to increase for a long period of time.
\end{abstract}

Key words: Mathematical Modeling, Diabetes Mellitus, Numerical Method

\begin{abstract}
Abstrak
Penyakit diabetes mellitus(DM) atau sering dikenal dengan penyakti diabetes, merupakan penyakit yang dapat disebabkan karena keturunan, salah satu faktor penyebabnya disebabkan pola pola hidup manusia. Pada paper diperkenalkan model dan analisis matematika berkaitan penyakit DM. Untuk mempermudah analisis, digunakan metode Runge Kutta untuk menyelesaikan model. Berdasarkan hasil analisis, diketahui bahwa populasi penderita penyakit DM cenderung bertambah untuk selang waktu yang cukup lama.
\end{abstract}

Kata Kunci: Pemodelan Matematika, Penyakit Diabetes Melitus, Metode Numerik.

\section{PENDAHULUAN}

Berdasarkan data International Diabetes Federation (IDF) jumlah orang yang menderita penyakit DM sekitar 183 juta orang, dan mereka tidak menyadari bahwa mereka menderita penyakit DM. diperkirakan terdapat sebesar $80 \%$ orang penderita DM yang tinggal di Negara berpenghasilan rendah dan menengah. Pada tahun 2006. Sedangkan dikawasan asia tenggara tercatat lebih dari 50 juta orang yang menderita DM [1]. Sedangkan Indonesia berada pada urutan ke-7 penderita DM terbesar di dunia. Dan sebanyak 8,5 juta oeang yang berusia 20-79 tahun [2].

Data menunjukkan, bahwa Provinsi Sulewasi Selatana khususnya di Kabupaten Bulukumba bahwa pada tahun 2013 terdapat 1150 orang yang terjangkit penyakit DM. Sedangkan pada tahun 2014 (januari-Agustus) sebanayk 143 pasien [3].

Penelitian sebelumnya,

1. N.Ardiansyah dan M.kharis menyimpulkan bahwa perawatan terhadap penderita DM tidak terlalu signifikan selama memiliki kebiasaan buruk khususnya pola makan.

2. Nanik Listiana menyimpulkan bahwa jumlah penderita DM akan terus bertambah dengan memperhatikan titik kesetimbangan.
Dengan masih banyaknya variable yang mempengaruhi penyakit DM sehingga pada paper ini akan dibuat model matematika DM dengan kompilasi Model matematika ini akan dianalisis berdasarkan titik kestimbangannya. Selanjutnya, model tersebut akan disimulasikan menggunakan data yang telah diperoleh dengan menggunakan metode numerik.

\section{Pemodelan Matematika}

Pemodelan matematika merupakan suatu proses dalam mateamtika dengan berdasarkana asumsiasumsi tertentu [4]. Secara umum proses pemodelan dilakukan dengan langkah sebagai berikut,

1. Menetukan masalah

2. Membuat asumsi dan pendekatannya

3. Menentukan model (persamaan matematika)

4. Menyelesaikan persamaan mateamtika (model matematika)

5. Membuat interpretasi berdasarkan solusi yang diperoleh.

\section{Titik Equilibrium}

Definisi. Misalkan $\dot{\boldsymbol{x}}=\boldsymbol{f}(\boldsymbol{x}) . \hat{x} \in R^{n}$ disebut titik equilibrium dari $\dot{\boldsymbol{x}}=\boldsymbol{f}(\boldsymbol{x})$. Jika memenuhi $f(\hat{x})=$ 0 .

Misalkan diberikan suatu sistem otonoums 


$$
\frac{d x}{d t}=f(x, y), \quad \frac{d x}{d t}=g(x, y)
$$

Titik $\left(x^{*}, y^{*}\right)$ disebut titik kritis dengan syarat $f\left(x^{*}, y^{*}\right)=0$ dan $\left.g, y^{*}\right)=0$. Maka Titik kritis $\left(x^{*}, y^{*}\right)$ adalah solusi sitem sistem (2.1) yang bernilai konstan $\left(\frac{d x}{d t}=0, \frac{d y}{d t}=0\right)[13]$.

Definisi Pelinearan. Misalkan fungsi $f=$ $\left\{f_{1}, \ldots, f_{n}\right\}, \quad \dot{x}=f(x) \quad$ dengan $f_{i} \in C(E), i=$ $1,2, \ldots, n$. Matriks

$$
\boldsymbol{J}(\boldsymbol{f}(\overline{\boldsymbol{x}}))=\left[\begin{array}{ccc}
\frac{\partial f_{1}(\bar{x})}{\partial x_{1}} \frac{\partial f_{1}(\bar{x})}{\partial x_{2}} & \ldots & \frac{\partial f_{1}(\bar{x})}{\partial x_{n}} \\
\frac{\partial f_{2}(\bar{x})}{\partial x_{1}} \frac{\partial f_{2}(\bar{x})}{\partial x_{2}} & \ldots & \frac{\partial f_{2}(\bar{x})}{\partial x_{n}} \\
\vdots & & \\
\frac{\partial f_{n}(\bar{x})}{\partial x_{1}} \frac{\partial f_{n}(\bar{x})}{\partial x_{2}} & \ldots & \frac{\partial f_{n}(\bar{x})}{\partial x_{n}}
\end{array}\right]
$$

Dinamakan matriks jacobian dari $f \operatorname{di} \operatorname{titik} \bar{x}$

\section{Stabil}

suatu titik kesetimbangan dikatakan stabil, jika dan hanya jika akar-akar karakteristiknya bernilai real dan negative.

\section{Tidak stabil}

Suatu titik setimbang dikatakan stabil jika hanya jika (nilai eigen) bernilai real positif atau mempunyai paling sedikit satu nilai eigen real positif.

\section{Metode Numerik}

Metode numerik merupakan suatu tekhnil untuk menyelesaikan rumusan matematika yang sulit diselesaikan dengan cara analitik [5]. Misalnya, persamaan differensial. Tidak semua persamaan diferensial bisa ditentukan solusinya dengan cara analitik. Sehingga diharuskan untuk memilih metode numerik. Diantaranya, metode Heun, Metode Euler, Runge-Kutta Ode 23 atau RungeKutta Ode 45.

\section{Metode Runge-Kutta}

Metode Runge-Kutta diperkenalkan oleh Carl Runge dan Martin Kutta pada tahun 1900 masehi. Metode Runge-Kutta merupakan salah satu alternatif dari metode deret Taylor dengan tidak membutuhkan turunan fungsi.

\section{Diabetes Melitus}

Diabetes Mellitus dikenal di Indonesia dengan istilah penyakit Gula atau kencing manis dengan ditandai kondisi gula darah overnormal atau melebihi gula darah normal yang disebabkan oleh tubuh kekuarangan insulin[6]. Dula darah dikategorikan berada pada kondisi normal dengan ketentuan [7]:
a. Kondisi sebelum makan 70 sampai 130 $\mathrm{mg} / \mathrm{dL}$
b. Selang 2 jam setelah makan kadar gula darah dkurang dari $180 \mathrm{mg} / \mathrm{dL}$
c. Tidak makan setelah 8 jam kondisi kadar gula darah kurang dari $100 \mathrm{mg} / \mathrm{dL}$
d. Menjelang tidur 100 sampai $140 \mathrm{mg} / \mathrm{dL}$

DM dikategorikan menjadi dua tipe yaitu DM Tipe 1 dan DM tipe II. Pada DM tipe 1, sel beta pankreas rusak mengakibatkan proses autoimun tidak dapat mengahsilkan insulin. Sehingga pada tipe ini pasien harus mendapatkan insulin. DM tipe 2, kebanyakan tipe ini diderita seseorang DM Gestasional, dan banyak terjadi pada pada ibu hamil [7].

Penyakit DM disebut sebagai the great imitator, merupakan penyakit yang dapat menyerang seluruh anggota tubuh. Oleh sebab itu DM dapat mengakibatkan terjadinya komplikasi pada tubuh baik berupa komplikasi akut ataupun kronis [8].

\section{METODOLOGI PENELITIAN}

Langkah-langakah yang dilakukan untuk menghasilkan model matematika DM adalah sebagai berikut:

1. Merumuskan masalah yang berkaitan dengan DM

2. Membuat asumsi berdasarkan observasi

3. Membuat persamaan matematika

4. Menentukan titik kesetimbangan

5. Menentkan nilai eigen $(\lambda)$

6. Membuat interpretasi berdasarkan hasil simulasi.

7. Melakukan validasi model

\section{HASIL DAN PEMBAHASAN}

1. Memformulasikan model real

Beberapa hal yang yang berkaitan dengan DM yaitu, DM adalalah gangguan metabolism, DM dapat menimbulkan komplikasi yang dapat berakibat fatal, Komplikasi diabetes dapat dicegah, ditunda atau diperlambat dengan mengontrol kadar gula darah, Mengontrol kadar gula darah dapat dilakukan dengan terapi misalnya patuh meminum oba, Kematian pada penderita DM berhubungan dengan komplikasi yang terjadi, Kelangsungan hidup penderita diabetes lebih panjang dan diabetes dapat dikontrol lebih lama degan pemberian beberap obat. (Restyana

\section{Membuat Asumsi}

Berdasarkan kondisi DM, dibuat asumsi sebagai berikut.
a) Terdapat kematian kematian secara alami disetiap kelas populasi.
b) Kasus baru dikategorikan sebaga kelas populasi DM tanpa komplikasi.
c) Terjadi kematian akibat komplikasi 
3. Formulasi model matematika

Berdasarkan asumsi di atas, peta kondisi populasi DM digambarkan pada grafik berikut.

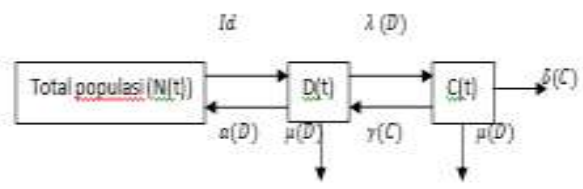

Berdasarkan grafik di atas diketahui bahwa $N(t)=$ $D(t)+C(t)$. Misalkan $\theta=\gamma+\delta+\mu$, dan $\sigma=$ $\lambda+\mu+\alpha$. Selanjutnya diberikan $\lambda=\beta \frac{C(t)}{N(t)}$, dimana konstanta $\beta$ merupakan koefisien pengendali untuk menentukan nilai $\lambda$. Diperoleh model sebagai berikut,

$$
\begin{aligned}
& \frac{d D}{d t}=I_{d}-\sigma D+\gamma C \\
& \frac{d C}{d t}=(\beta-\theta) C-\beta \frac{C^{2}}{N} \\
& \frac{d N}{d t}=I_{d}-\mu N-\delta C-\alpha D
\end{aligned}
$$

\section{Titik Equilibrium}

Titik equilibrium diperoleh dengan ketentuan $\frac{d D}{d t}=$ $0, \frac{d C}{d t}=0, \frac{d N}{d t}=0$, yang bermakna bahwa tidak terjadi populasi untuk setiap t. diperoleh titik equilibrium sebagai berikut:

$$
\begin{aligned}
& \left(D^{*}, C^{*}, N^{*}\right)=\left(\frac{I_{d}}{\sigma}, 0, \frac{I_{d}(\sigma-\alpha)}{\sigma \mu}\right) \\
& D^{*}=i_{d}\left(\frac{1+(\gamma(\beta-\theta)(\sigma-\alpha))}{\mu \beta \sigma^{2}}\right) \\
& C^{*}=\left(\frac{I_{d}(\beta-\theta)(\sigma-\alpha)}{\mu \sigma \beta}\right) \\
& \quad N^{*}=I_{d}\left(\frac{(1-(\delta \sigma p q)-(\alpha(1+\gamma p q)))}{\beta \mu^{2} \sigma^{2}}\right)
\end{aligned}
$$

\section{Pelinearan Pada Titik Tetap}

Pelinearan dilakukan menggunakan matriks Jacobian, yaitu

$$
J\left(D^{*} C^{*} N^{*}\right)=\left[\begin{array}{ccc}
-\sigma & 0 & \gamma \\
0 & (\beta-\theta)-2 \beta \frac{C^{*}}{N^{*}} & \beta \frac{\left(C^{*}\right)^{2}}{\left(N^{*}\right)^{2}} \\
-\alpha & -\delta & -\mu
\end{array}\right]
$$

\section{Menentukan Nilai Eigen}

Dari matriks Jacobian diperoleh nilai Eigen yaitu: $\lambda_{1}=-\mu, \lambda_{2}=-\sigma, \lambda_{3}=\beta-\theta$,

\section{Simulasi Model}

Data yang digunakan adalah data pasien penderita DM di RSUD kabupaten Bulukumba. Dengan $I_{d}=$ 1170. Berdasarkan data dari RSUD kota Bulukumba diketahui:
1. bahwa Jumlah penderita DM sebanyak 1170

2. dari 1700 penderita DM terdapat 1000 jiwa dengan komplikasi 1000 jiwa dan dan sisanya tanpa komplikasi.

Tabel 1. Parameter

\begin{tabular}{|c|l|}
\hline parameter & $\begin{array}{l}\text { Nilai } \\
\left(y r^{-1}\right)\end{array}$ \\
\hline$\mu$ & 0,020 \\
\hline$\delta$ & 0,050 \\
\hline$\alpha$ & 0,040 \\
\hline$\gamma$ & 0,080 \\
\hline$\beta$ & 1,00 \\
\hline$\lambda$ & 0,850 \\
\hline
\end{tabular}

Berikut ini adalah simulasi model pencarian kestabilan titik tetap pada saat masih terdapat penderita yang mengalami kesembuhan. Dengan memisalkan nilai parameter yaitu $=0,02, \delta=$ $0,05, \alpha=0.04, \gamma=0,08, \beta=1$, dan $\lambda=0,85$. Pada kondisi ini tingkat kesembuhan komplikasi $\gamma$ pada penderita DM sebesar 0,08 maka diperoleh $\theta=0,15$ sehingga jika disubtitusikan ke dalam Sistem Persamaan (4.2) akan diperoleh seperti berikut ini:

$$
\begin{aligned}
\frac{d D}{d t}= & 1170-(0,91) D+0,08 C \\
\frac{d C}{d t}= & (1-0,15) C-\frac{C^{2}}{N} \\
& 0,85 C-\frac{C^{2}}{N} \\
\frac{d N}{d t}= & 1170-0,02 N-0,05 C-0,04 D
\end{aligned}
$$

Kestabilan dari Sistem (4.3) dapat diselidiki melalui nilai eigen dari matriks jacobiannnya yang telah diperoleh yaitu $\lambda_{1}=-0,02, \lambda_{2}=-0,91$ dan $\lambda_{3}=$ 0,85 . dapat dilihat bahwa salah satu nilai eigennya merupakan bilangan real positif, maka titik $\left(D^{*}, C^{*}, N^{*}\right)=(1285,71,0,55928,57) \quad$ tidak stabil.

Selanjutnya Kestabilan dari sistem bergantung pada nilai eigen dari matriks jacobiannya yang diperoleh yaitu $\lambda_{1}=-0,02, \lambda_{2}=-0,91$, dan $\lambda_{3}=0,97$. Dapat dilihat salah satu dari nilai eigen merupakan bilangan real positif, maka perilaku sistem di sekitar titik $\left(D^{*}, C^{*}, N^{*}\right)=(74822,92$, $47539,29,3263688)$ adalah tidak stabil.

Dengan menggukan metode runge kutta dapat diketahui laju perubahan populasi penderita DM, dapat dilihat pada tabel dan grafik berikut.:

Tabel 4.2. Laju perubahan populasi penderita DM

\begin{tabular}{|l|l|}
\hline loop & $\begin{array}{l}\text { Runge Kutta Orde-4 } \Delta x= \\
0,1\end{array}$ \\
\hline
\end{tabular}




\begin{tabular}{|l|l|l|l|}
\hline & $\mathrm{D}$ & $\mathrm{C}$ & $\mathrm{N}$ \\
\hline 1 & 275,0 & 1003,0 & 1279,0 \\
\hline 2 & 370,0 & 1013,0 & 1387,0 \\
\hline 3 & 458,0 & 1027,0 & 1494,0 \\
\hline 4 & 538,0 & 1046,0 & 1601,0 \\
\hline 5 & 611,0 & 1068,0 & 1707,0 \\
\hline 6 & 678,0 & 1094,0 & 1812,0 \\
\hline 7 & 739,0 & 1122,0 & 1917,0 \\
\hline 8 & 795,0 & 1153,0 & 2022,0 \\
\hline 9 & 847,0 & 1186,0 & 2125,0 \\
\hline 10 & 894,0 & 1222,0 & 2284,0 \\
\hline
\end{tabular}

Tabel 4.2 di atas menunjukkan laju populasi semakin meningkat setiap waktu (tahun). Selain pada tabel di atas laju perubahan populasi penderita DM juga dapat dilihat pada Gambar berikut

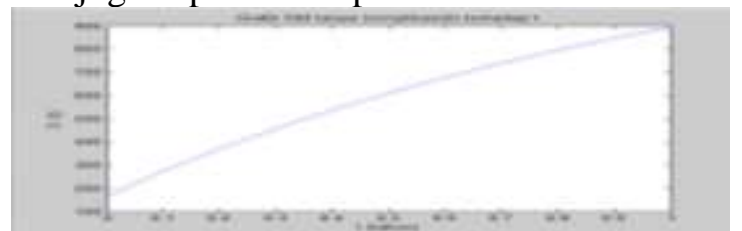

Gambar 4.1. Grafik Laju perubahan poppulasi penderita DM tanpa Komplikasi

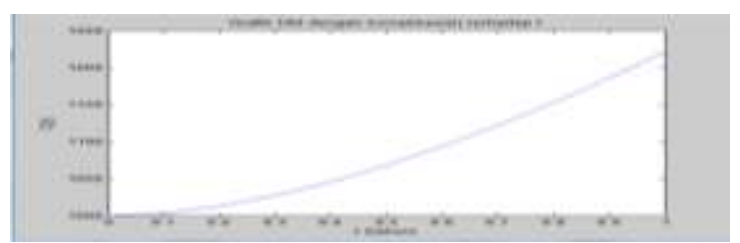

Gambar 4.2. Grafik Laju Perubahan Populasi Penderita DM dengan Komplikasi

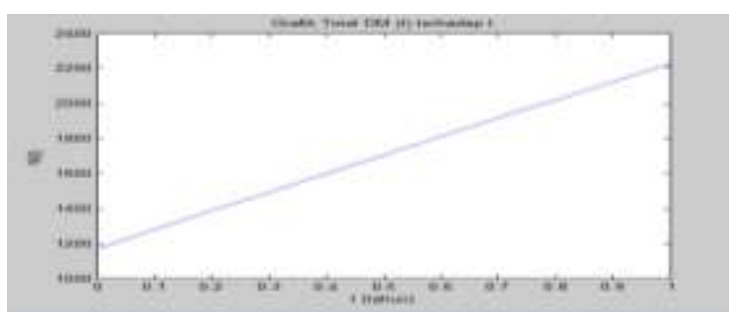

Gambar 4.3. Grafik Laju Perubahan Total Populasi Penderita DM

Berdasarkan ketiga gambar di atas (Gambar 4.1, 4.2, 4.3) di menjelaskan bahwa laju pertumbuhan populasi penderita DM tanpa dan dengan komplikasi serta total populasi terhadap waktu semakin meningkat.

a. Kondisi saat tidak terdapat penderita yang mengalami kesembuhan komplikasi
Simulasi selanjutnya yaitu pada kondisi saat tidak ada penderita yang sembuh dari komplikasi atau $\gamma=0$. Dengan memisalkan nilai parameter yaitu $=$ $0,02, \delta=0,05, \alpha=0,04, \gamma=0, \beta=1$, dan $\lambda=0,85$. maka diperoleh $\theta=0,07$ sehingga jika disubstitusikan ke dalam Persamaan (4.2) akan diperoleh seperti berikut

$$
\begin{aligned}
& \frac{d D}{d t}=1170-(0,91) D+0 \\
& \frac{d C}{d t}=(1-0,07) C-\frac{C^{2}}{N} \\
& \quad=0,93 C-\frac{C^{2}}{N} \\
& \frac{d N}{d t}=1170-0,02 N-0,05 C-0,04 D
\end{aligned}
$$

Kestabilan dari Sistem (4.4) dapat diselidiki melalui nilai eigen dari matriks jacobiannnya. Diperoleh nilai eigen yaitu $\lambda_{1}=-0,02, \lambda_{2}=-0,91$ dan $\lambda_{3}=0,85$. dapa dilihat bahwa salah satu nilai eigennya merupakan bilangan real positif, maka titik $\quad P_{0}\left(D^{*}, C^{*}, N^{*}\right)=(1285,714,0,55928,57)$ tidak stabil.

Selanjutnya kestabilan dari diperoleh nilai eigen yaitu $\lambda_{1}=-0,02, \lambda_{2}=-0,9$, dan $\lambda_{3}=0.968$. Nilai eigen yang diperoleh yang merupakan bilangan real negative dan positif, maka perilaku sistem disekitar titik $P_{1}\left(D^{*}, C^{*}, N^{*}\right)=(70643,64$, $52013,57,32608861)$ dapat dikatakan tidak stabil.

Berikut diberikan laju perubahan populasi penderita DM dengan menggunakan metode Runge Kutta

Tabel 4.3. Laju perubahan populasi penderita DM

\begin{tabular}{|l|l|l|l|}
\hline \multirow{2}{*}{$\begin{array}{l}\text { Iteasi } \\
\text { ke- }\end{array}$} & \multicolumn{3}{|l}{ Runge } \\
Dengan $(\Delta x)=0,1$
\end{tabular}

Tabel 4.3 di atas menunjukkan laju populasi semakin meningkat setiap waktu (tahun). Selain 
pada tabel di atas laju perubahan populasi penderita DM juga dapat dilihat pada Gambar berikut:

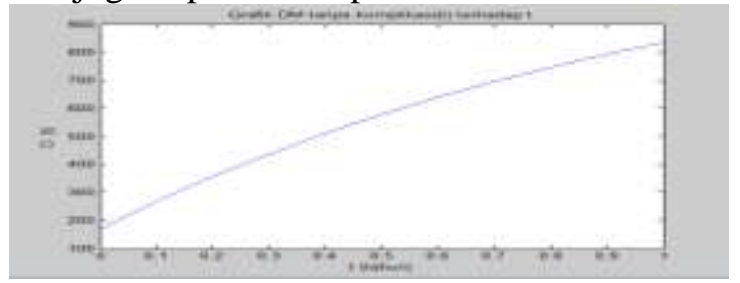

Gambar 4.4. Grafik Laju Perubahan populasi penderita DM tanpa Komplikasi

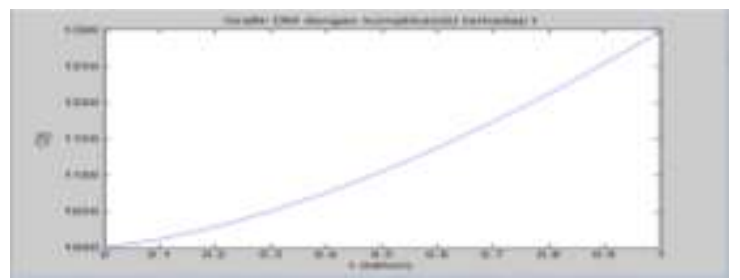

Gambar 4.5. Grafik laju perubahan populasi penderita DM dengan komplikasi

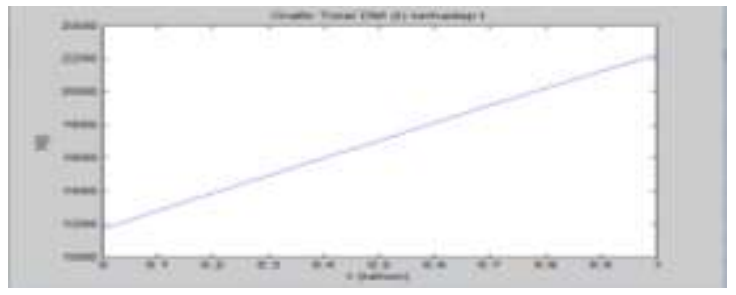

Gambar 4.6. Grafik laju perubahan total populasi penderita DM

Berdasarkan ketiga gambar di atas (Gambar 4.4, 4.5, 4.6) di menjelaskan bahwa laju pertumbuhan populasi penderita DM tanpa dan dengan komplikasi serta total populasi terhadap waktu semakin meningkat

Berdasarkan nilai kestabilan dari kedua kondisi diatas dapat dikatakan bahwa nilai $\gamma$ tidak membawa pengaruh terhadap kestabilan sistem. Akan tetapi kenaikan nilai $\gamma$ mampu mengurangi jumlah populasi penderita DM dengan komplikasi

\section{Pembahasan}

Pada penelitian ini, untuk memperoleh tujuan yang ingin dicapai terlebih dahulu mengumpulkan datadata yang berkaitan dengan penyakit DM tanpa dan dengan Komplikasi. Data yang diperoleh kemudian dibuat menjadi asumsi-asumi yang akan digunakan untuk membentuk model matematika. Sehingga diperoleh model pada Persamaan (4.1).

Pada persamaan (4.1) model pertama dapat dilihat laju pertumbuhan populasi penderita DM dipengaruhi dengan adanya insiden penyakit DM yang artinya adanya individu yang didiagnosa menderita DM yang diasumsikan konstan,. Adanya individu yang sembuh dari komplikasi, selain itu juga dipengaruhi dengan adanya kematian alami proporsi DM meningkat ke taraf komplikasi dan adanya laju individu yang berhasil menormalkan gula darah yang demikian dapat mengurangi laju pertumbuhan penderita DM tanpa komplikasi.

Pada persamaan (4.1) model kedua dapat dilihat bahwa populasi tanpa komplikasi dipengaruhi oleh proporsi individu yang menjadi komplikasi, semakin banyak penderita individu yang mengalami komplikasi teasi maka jumlah populasi pada penderita DM dengan komplikasi akan semakin meningkat dan ini menandakan bahwa laju kematian individu juga akan semakin meningkat setiap waktu.

Model yang terbentuk merupakan persamaanpersamaan diferensial yang kemudian diselesaikan dengan membentuk model baru. Model yang terbentuk dapat dilihat pada sistem Persamaan (4.2). pada sistem ini terbentuk sistem persamaan non linear. Kemudian dari model tersebut ditentukan nilai titik kesetibangan dan titik kestabilannya.

\section{KESIMPULAN}

Model matematika terhadap kelangsungan hidup penderita DM yaitu:
a. $\frac{d D}{d t}=I_{d}-\sigma D+\gamma C$
b. $\frac{d C}{d t}=(\beta-\theta) C-\beta \frac{C^{2}}{N}$
c. $\frac{d N}{d t}=I_{d}-\mu N-\delta C-\alpha D$

Kestabilan model matematika terhadap kelangsungan hidup penderita DM berdasarkan syarat kestabilannya diperoleh kondisi yang tidak stabil. Dengan kata lain bahwa populasi penderita DM akan selalu ada dan terus meningkat. Hal ini menandakan bahwa jumlah kematian yang disebabkan penyakit DM akan selalu ada dan terus meningkat.

Dalam paper ini penulis menggunakan variabel tanpa komplikasi dan dengan komplikasi. Untuk penelitian selanjutnya dapat menggunakan variabel dan parameter lain seperti berbagai jenis penggunaan obat untuk melihat pengaruhnya terhadap kelangsungan hidup pada penderita diabetes melitus. 


\section{DAFTAR PUSTAKA}

[1] T. K. Shara, "Faktor Resiko Kejadian Diabetes Melitus Tipe Ii Di Puskesmas Kecamatan Cengkareng Jakarta Barat Tahun 2012," Jurnal ilmiah kesehatan FKM STIKes MH. Thamrin, p. vol. 5. no.1, 2012.

[2] d. M. Efendi, "Pemodelan matematika dan Analisis Kestabilam lokal Pada Perubahan Populasi Penderita Diabetes Melitus," Bimaster, p. 5, 2015.

[3] I. maulana, Analisis Komplikasi Yang berhubungan dengan kejadian silent coronary artery disease pada pasien riwayat diabetes melitus tipe 2 (TESIS), 2012.

[4] E. Cahyono, Pemodelan Matematika, Yokyakarta: Graha Ilmu, 2013.

[5] Supinah, Modifikasi Metode Runge-Kutta Orde 4 (Kutta) Berdasarkan Rata-Rata Kontra Harmonik. (Skripsi), RIAU: UIN Sultan Syarif kasim RIAU, 2011.

[6] N. F. S. I Nyoman Budiantara, "Analisis survival dengan pendekatan multivariate adaptive regression splines pada kasus demam berdarah dengue," Sains dan Seni, 2012.

[7] Hasdiana, Mengenal Penyakit Diabetes pada Orang Dewasa dan Anak anak dengan solusi Herbal, Kedir: Nuha Medika, 2012.

[8] Mardikawati, "Penanganan penderita diabetes melitus RSUD H>A Sulthan Daeng Radja Kabupaten Bulukumba," 2015.

[9] Y. Ramadani, "Berapa Kadar Gula Darah Normal," 17 Oktober 2018. [Online]. Available: https://tirto.id/berapa-kadar-guladarah-normal-c7jR.

[10] M. d. Ardiansyah, "Model Matematika untuk Penyakit Diabetes Tanpa Faktor Genetik.," Jurnal MIPA, p. 35, 2012.

[11] I. Juliah, Analisis kestabilan titik kesetimbangan model matematika proses transmisi virus dengue di dalam tubuh manusia dengan terapi obat herbal (SKRIPS), Semarang: FMIPA UNESA, 2015.
[12] W. d. Listiana nanik, "Analisis kestabilan Model matematika dari Popupasi penderita diabetes Melitus," 2012.

[13] R. Munir, Metode Numerik Revisi Kedua, Bandung: Informatika, 2008.

[14] S. L. Yulianar, titik kesetimbangan model matematika pada pertumbuhan sel $\mathrm{T}$ yang mensekresi interlekuin-2 (SKRIPSI), Malang: UIN Malik Ibrahim, 2009. 